\title{
TWO NEW FISSIDENS SPECIES (FISSIDENTACEAE) FROM TROPICAL EASTERN AFRICAAND FISSIDENS BESSOUENSIS CORB., A REMARKABLE SPECIES WITH FIMBRIATE LEAVES AND MULTICELLULAR SPORES ${ }^{1}$
}

\author{
MARIA ALIDA BRUGGEMAN-NANNENGA
}

\begin{abstract}
Fissidens acrophilus Bruggeman-Nannenga, sp. nov. (subgenus Fissidens) from Kenya and Uganda and F. obscurifrons Bruggeman-Nannenga, sp. nov. (subgenus Fissidens?) from Tanzania are newly described and figured. F. obscurifrons is compared to the little known Madeiran F. nobreganus Luisier \& P. de la Varde. A revision of $F$. bessouensis Corb. (subgenus Octodiceras) with description, diagnosis and figures and a discussion including adaptations to an aquatic habitat is presented. Multicellular spores and fimbriate leaf margins are reported in the Fissidentaceae for the first time. Rectification: F. angustelimbatus Mitt. is eliminated from the African flora.
\end{abstract}

Key words: Taxonomy, Africa, Fissidens acrophilus spec. nov., Fissidens obscurifrons spec. nov., Fissidens nobreganus, Fissidens bessouensis, fimbriate leaves and multicellular spores in Fissidens

Maria Alida Bruggeman-Nannenga, Griffensteijnseplein 23, 3703 BE Zeist, The Netherlands

While preparing a paper on subgenus Fissidens in tropical eastern Africa two new species were discovered. Both are from wet habitats. Fissidens acrophilus Bruggeman-Nannenga, sp. nov. is a limbate species with smooth cells found on Mt. Elgon (Kenya and Uganda) between 3250 and $3960 \mathrm{~m}$. Fissidens obscurifrons Bruggeman-Nannenga, $s p$. nov. has smooth cells and partly limbate leaves. It was collected by Tamás Pócs and collaborators in the Nguru and S-Pare Mts in Tanzania and grows between 700 and $1000 \mathrm{~m}$. The last part of this paper is a revision of the West African $F$. bessouensis Corb. (subgenus Octodiceras). This remarkable species has two features that are to my knowledge hitherto unknown in the Fissidentaceae: fimbriate leaf margins and multicellular spores.

Fissidens acrophilus Bruggeman-Nannenga, sp. nov. Fig. 1

TYPE: KENYA. Mount Elgon National Park, at the Suam River sources $1 \mathrm{~km}$ WSW of Koitoboss summit. Carex runssorensis-Alchemilla bog, on peaty soil.

\footnotetext{
1 With pleasure I dedicate this paper to Professor Tamás Pócs for his $80^{\text {th }}$ birthday.
}

3960 m. 17 January 1992. Kungu 9222/AD (HOLOTYPE: L; ISOTYPE: EGR).

DESCRIPTION (perigonial data from paratype). Growing in mats; stem with central strand of \pm 10 cells, with $1-3$ tiers of inner and $1-3$ tiers of outer cortical cells; rhizoids basal and frequently axillary, brown, smooth; axillary nodules weakly differentiated; perichaetial stems shorter than vegetative stems; vegetative stems branched or not, 8.0-10.0 × 2.0-2.5 mm, pinnate; leaves pale green, older leaves often with dark costa and limbidia, distant to partly overlapping, up to 20 pairs, hardly crispate when dry, broadly lanceolate, acute-acuminate to acute-mucronate, $1.10-1.30 \times 0.40-0.45$ $\mathrm{mm}, \mathrm{L} / \mathrm{W} 3$, limbate; limbidium \pm reaching the leaf apex, confluent or not; confluent at the apex of the vaginant lamina, reaching the insertion of the vaginant lamina; reaching the insertion of the dorsal lamina, becoming indistinct on the decurrency, in mid of dorsal lamina $24 \mu \mathrm{m}$ wide, 1-2 stratose; on vaginant laminae to 6 cells wide, to $38.5 \mu \mathrm{m}$ wide, 1-2 stratose, marginal; vaginant lamina $4 / 5$ the leaf length, slightly open to closed, at the base less wide to about as wide as the stem, slightly rounded at insertion, not decurrent, unistratose; 
dorsal lamina narrow, slightly rounded at base, reaching the insertion, often slightly decurrent, dorsal and apical lamina unistratose; costa perto excurrent; mid dorsal laminal cells hexagonal, plane to slightly convex, $10-18 \times 7-10 \mu \mathrm{m}$, smooth; mid vaginant laminal cells $10.0-20.5 \times$ 5.0-11.0 $\mu \mathrm{m}$; gemmae not observed.

Fertile parts. Cladautoicous, perigonia terminal on short, axillary branches, budlike or slender, 0.3-0.7 mm long, antheridia $200 \mu \mathrm{m}$ long; perichaetia terminal on short stems and short branches; perichaetial stems, 2-3 $\times 1 \mathrm{~mm}$, unbranched, frondiform, in clusters at the base of vegetative stems; leaves crowded, up to 5 pairs, perichaetial leaves up to $1.7 \mathrm{~mm}$ long; archegonia $\pm 300 \mu \mathrm{m}$ long; sporophyte, seta $6 \mathrm{~mm}$ long, smooth; capsule symmetrical to slightly oblique, $0.7-0.9 \times 0.5 \mathrm{~mm}, \pm 64$ columns of oblong exothecial cells; peristome bryoides type, teeth 45.0-49.5 $\mu \mathrm{m}$ wide at base, relatively short, $250 \mu \mathrm{m}$ long; operculum $0.45 \mathrm{~mm}$ long; calyptra not seen; spores subglobose, 16.5-19.5 $\mu \mathrm{m}$, coarsely papillose, green.

ETYMOLOGY. The name acrophilus is derived from the Greek words $\alpha \kappa \rho о \nu$ (topmost) and pí̀oo (loving) indicating that it grows at high altitudes.

SUBSTRATE. On peaty soil, wet rocks.

HABITAT. Carex runssorensis-Alchemilla bog; afro-alpine zone unspecified.

Altitude. 3250-3960 m.

Distribution. So far known only from Mt Elgon (Kenya and Uganda).

PARATYPE: UGANDA, Mt Elgon, wet rocks in afroalpine zone, on wet soil. Wesche 9085 (private herbarium Bruggeman-Nannenga).

This new species is known from high altitudes in Kenya and Uganda. It is characterized by its pale green, limbate, slightly decurrent, broadly lanceolate, acute-acuminate to acute-mucronate leaves with per- to excurrent costae and large, $10.0-19.0 \times 7.0-11.5 \mu \mathrm{m}$, laminal cells; it has long, pinnate stems with basal clusters of short, frondiform perichaetial stems and short, axillary perichaetial and perigonial branches; and short peristomal filaments. Variability: the type specimen differs from the other collection in the relatively long vaginant laminae. Fissidens acrophilus can be confused with large expressions of $F$. curvatus. This species can be distinguished by its limbidia that are confluent at the apex and its narrower, stiff vegetative leaves with dorsal laminae that are not decurrent. Fissidens androgynus can be separated by its terminal antheridia and archegonia. The type-specimen was earlier reported as F. anguste-limbatus Mitt. (BruggemanNannenga 2009); indeed, it resembles this species in the shape of the leaves, and the dark brown coloring of cell walls, costae and limbidia in older specimens. However, F. anguste-limbatus has no central strand, lacks axillary nodules and has archegonial plants that are similar to vegetative stems. Moreover, it is typically found at lower elevations, 0 and $1200 \mathrm{~m}$, though once at 3200 m (Pursell 2007).

The new species belongs in subgenus Fissidens as it has limbate leaves, smooth cells and a bryoides type peristome.

Fissidens obscurifrons Bruggeman-Nannenga, sp. nov.

Fig. 2

TYPE: TANZANIA. Nguru Mts, Kanga Forest Reserve, on the SE slope of Mt Kanga. Lowland rainforest, on irrigated rocks under small waterfall. $700-800 \mathrm{~m}$. 4 December 1987. Pócs, Nsolo \& Temu 87226/AL (HOLOTYPE: L; ISOTYPE: EGR).

Growing from a dense mat of rhizoids, thalloid protonemata (Fig. 2: 11) present or not; central strand weak or lacking, with 1-2 tiers of inner and 2 tiers of outer cortical cells; rhizoids basal, bright

Fig. 1. Fissidens acrophilus Bruggeman-Nannenga, sp. nov. 1 - vegetative stem with small, basal perichaetial stem; 2 - vegetative stem; 3 - sporophytic stem; 4 - short perichaetial stem (detail from 1); 5-8 - leaves; 9 - perichaetial leaf; 10-12 - leaf apices; 13 - mid leaf; $14 \mathrm{~b} \& 15$ - basal parts of leaf with decurrent dorsal lamina; 16 - axillary nodule. 1-4, 7-10 and 12-14 from holotype Kungu 9222/AD (holotype: L); 5-6, 11, 15, 16 from Wesche 9085 (paratype: private herbarium BruggemanNannenga). 


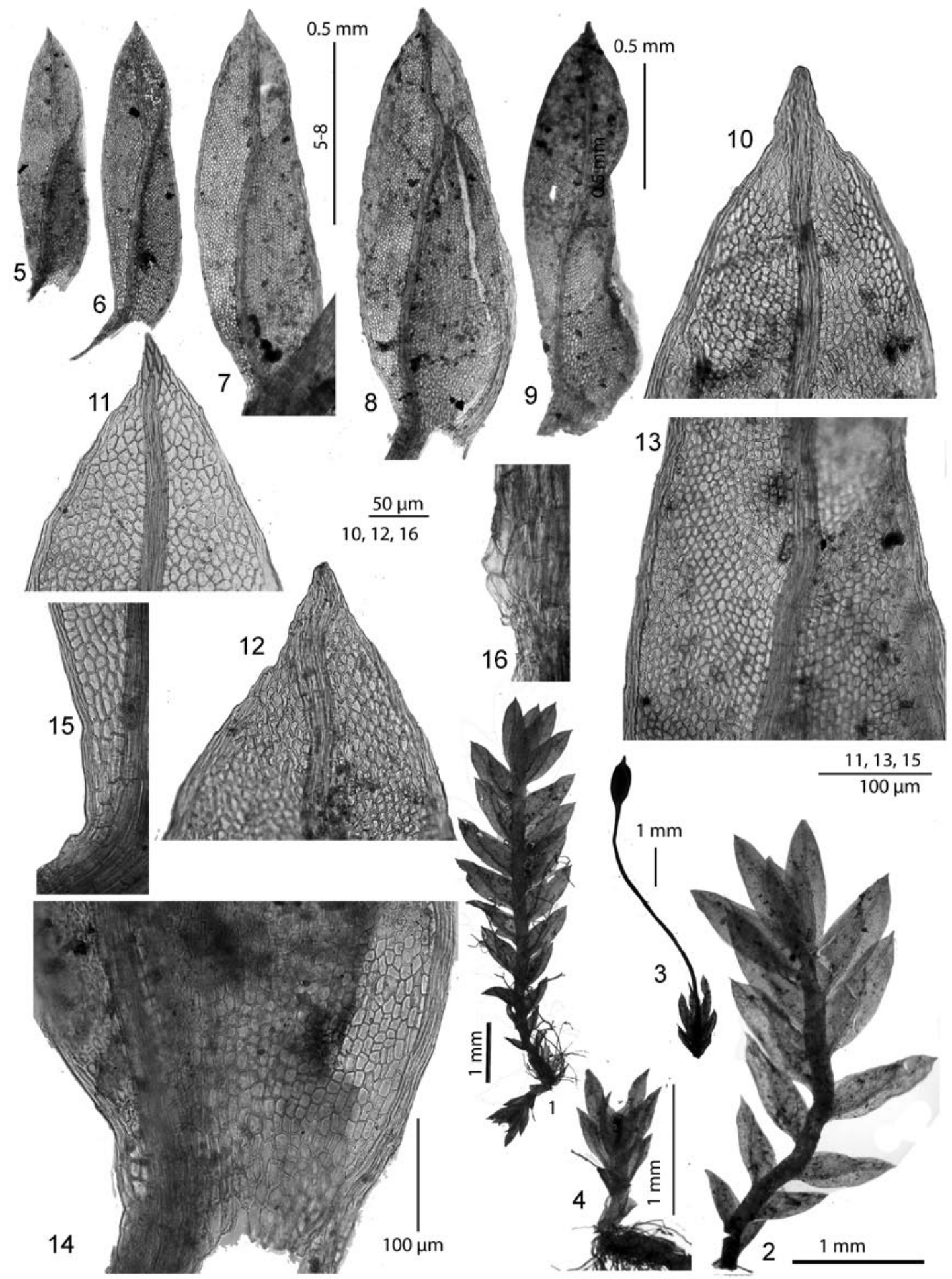


brown, smooth, up to $33 \mu \mathrm{m}$ wide; axillary cells weakly differentiated; stems unbranched, 1.5-3.5 $\times 0.8-1.7 \mathrm{~mm}$, pinnate; leaves distant to close, up to 13 pairs, hardly altered when dry, obscure, elliptical, elliptico-lanceolate and oblanceolate, acute, $0.5-1.0 \times 0.1-0.6 \mathrm{~mm}, \mathrm{~L} / \mathrm{W} 3-9$, margin subentire, partly limbate, poorly developed plants sometimes elimbate throughout; limbidium mostly restricted to the vaginant lamina and basal part (up to $150 \mu \mathrm{m}$ ) of the apical lamina, on dorsal laminae lacking or represented by a few cells in the mid part; on mid of dorsal lamina 0-16 $\mu \mathrm{m}$ wide, unistratose; on the vaginant lamina 0-3 cells wide, $16 \mu \mathrm{m}$ wide, unistratose, marginal or intramarginal; vaginant lamina $1 / 2-3 / 5$ the leaf length, closed to slightly open, at the insertion less wide than the stem, slightly concave, not decurrent, unistratose; dorsal lamina narrow, hardly rounded at the insertion, reaching the insertion, not decurrent, dorsal and apical lamina unistratose with bistratose areas, alongside the costa and near the insertion uni- to bistratose; costa ending 5-7 cells below the leaf apex; mid dorsal laminal cells hexagonal, 5.0-11.5 × 5-8 $\mu \mathrm{m}$, smooth; mid vaginant laminal cells $6-13 \times 3-8 \mu \mathrm{m}$. Fertile parts unknown.

ETYMOLOGY. The name refers to the obscure leaves. From the Latin words obscurus (dark) and frons (frond).

HABITAT. Near and under small waterfalls; riverine and lowland rainforests.

SUBSTRATE. Shady rocks; on irrigated rocks.

Altitude. 700-1000 m.

Distribution. Tanzania, S-Pare Mts and Nguru Mts.

PARATYPE: TANZANIA, S-Pare Mts, on the E slope of Mt Kwizu, WNW of Kisiwani village. Riverine forest, on shady rocks near small waterfalls, $1000 \mathrm{~m}, 27$ June 1972, Pócs $6716 / J$ mixed with $F$. robynsianus and F. leucocinctus (EGR, L).
This new species is only known by its vegetative state. It is characterized by typically narrow, obscure, elliptical, elliptico-lanceolate to oblanceolate leaves; limbate vaginant laminae with limbidia extending up to $150 \mu \mathrm{m}$ onto the apical laminae limbate; dorsal laminae frequently elimbate. Both collections grow on a mat of up to $33 \mu \mathrm{m}$ wide rhizoids mixed with diatoms and branched cyanophytes. In its leaf shape and obscure leaves the new species resembles the little known Madeiran endemic F. nobreganus Luisier \& P. de la Varde, but in this species vegetative stem leaves are elimbate. Moreover, $F$. nobreganus is not hydrophilous. The new species further could be taken for a miniature $F$. leucocinctus. This species can be distinguished by its larger, typically wider (L/W 3-4), limbate leaves, stout 3-5 stratose limbidia and by larger size (stems $5-30 \times 2-3 \mathrm{~mm}$ ). From the also partly limbate $F$. bogosicus Müll. Hal. it differs by the obscure, typically narrower leaves. The new species probably belongs in subgenus Fissidens, but subgenus Aloma cannot positively be excluded without sporophyte.

SPECIMEN EXAMINED FOR COMPARISON: Fissidens nobreganus Luisier \& P. de la Varde: Madère, sur le tronc de Ocotea foetens. Nord de l'Isle. 1 X 1952. Nóbrega s.n. (TYPE: PC-PV, slide).

\section{FISSIDENS BESSOUENSIS CORB.}

In 2006 Alain Vanderpoorten and Eberhard Fisher collected a number of Fissidens specimens in Gabon. Amongst these was an aquatic species with fimbriate leaf margins. Having never before seen a Fissidens with fimbriate leaves the first thought was that this represented an undescribed species close to F. bessouensis Corb. However, an examination of several specimens of this species, including the type, showed that fimbriae were often present. Further examination of the specimens showed that spores of $F$. bessouensis are multicellular (type specimen and in Overlaet s.n.). Apart

Fig. 2. Fissidens obscurifrons Bruggeman-Nannenga, sp. nov. 1 - vegetative plant; 2-5 - leaves; 6 - leaf apex; 7 - mid leaf with elimbate dorsal lamina; 8 - mid leaf with weakly limbate dorsal lamina; 9 - detail of 8 ; 10 - basal part of leaf; 11 - rhizoids with thalloid protonemata - 1, 5-7 from Pócs, Nsolo \& Temu 87226/AL (holotype L), 2-4, 8-11 from Pócs 6716/J (paratype: L). 

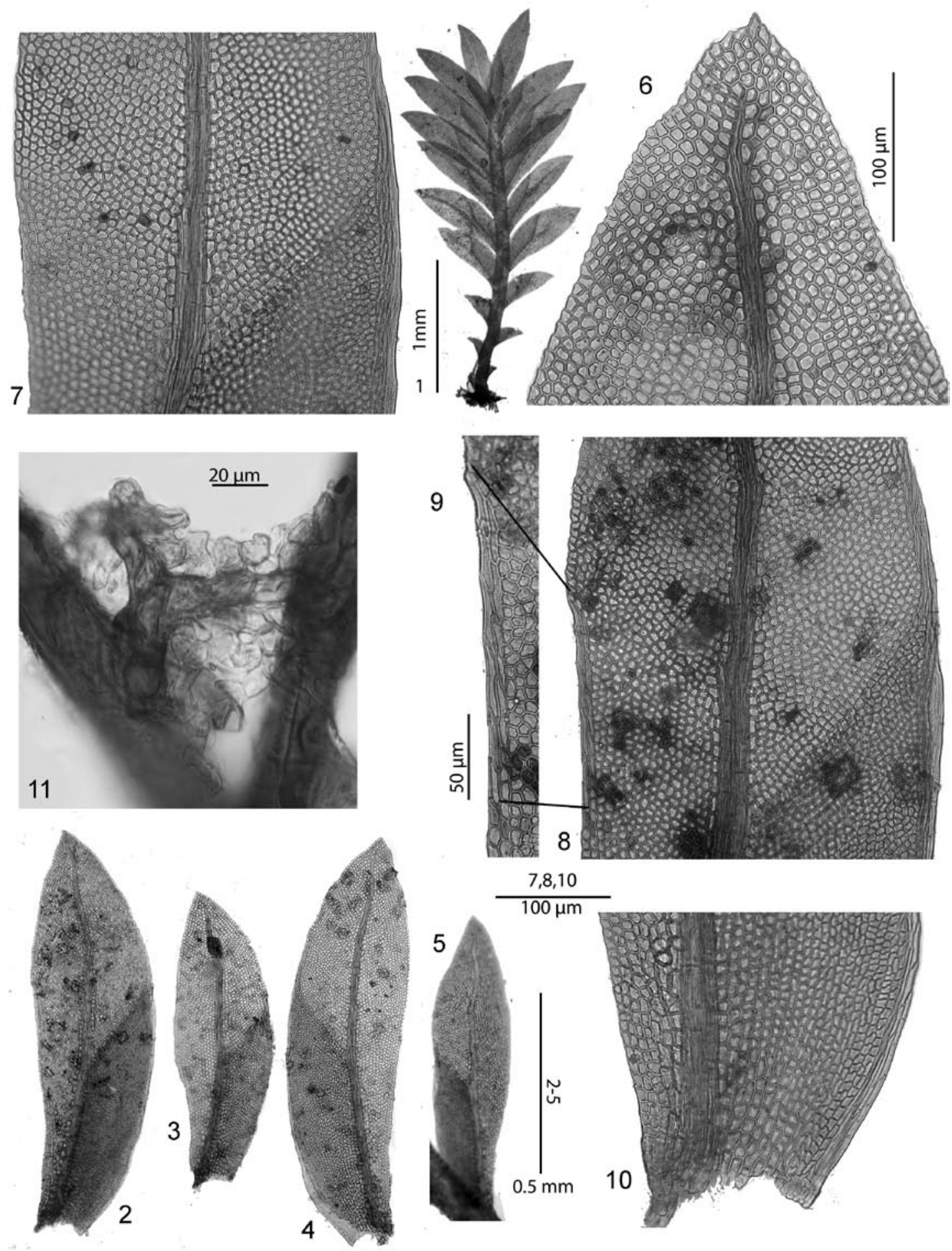
from these two unique features, $F$. bessouensis is also remarkable for its rostrate perichaetial leaves and subsessile thecae which made Pursell (1987) observe that $F$. bessouensis is truly a most remarkable species of Fissidens.

\section{Fissidens bessouensis Corb.}

Fig. 3

Bull. Mus. Natl. Hist. Nat. 18: 109. 1912 - TYPE: Central African Republic [Haut-Oubangui], Bessou, le long des rives du fleuve, entre Bangui et le confluent de la Kémo. Pendant des branches des arbres à la hauteur atteinte par les cruz. 2 Sept 1902. Chevalier s.n. (HOLOTYPE: PC; ISOTYPE: PC-PV). Pursell (1987) cited the specimen in Potier de la Varde's herbarium (PC-PV) as holotype. Since the species was described by Corbière the specimen in this author's herbarium in PC must be the holotype.

Fissidens jordanii J. Taylor \& P. de la Varde, Bull. Misc. Inform. Kew 1954: 505, f. A-E. 1954 - TYPE: Sierra Leone, Mange, Bure. Epiphytic on small shrub (Croton scarceisii Sc. Elliot) abundant on rocks now exposed in river. 5. I. 1953. H. D. Jordan $851 A$ (LECTOTYPE designated by Bruggeman-Nannenga \& Pursell 1995: PC-PV; ISOLECTOTYPES: BM).

Vegetative parts. Stems firmly attached to the substrate, floating, greatly branched, 50-100 $\times 1.5-5.0 \mathrm{~mm}$ (with branches), pinnate; central strand lacking, 2-6 tiers of inner and 1-8 tiers of small to large outer cortical cells; rhizoids plentiful, basal and along the stem, axillary or not, and apically on leaves, brown, smooth; axillary nodules weakly or not differentiated; leaves green, numerous, typically distant, slightly crispate when dry, linear elliptico-lanceolate, acute, 2.0-4.0 $\times$ 0.3-0.7 mm, L/W 5-10; margin subentire, frequently irregular by protruding cells (fimbriae initials) or fimbriate on all laminae, entire in proximal part of vaginant lamina, elimbate or weakly limbate (best seen in $5 \% \mathrm{KOH}$ ) on basal $1 / 4$ part of vaginant lamina; limbidium unistratose, $1-5$ cells wide, to $17.5 \mu \mathrm{m}$ wide, marginal; vaginant lamina $2 / 5-2 / 3$ the leaf length, basally narrower than the stem, narrow and straight towards the insertion, then frequently suddenly widened at the insertion, slightly decurrent or not, unistratose, nearly or completely open (infrequently slightly open), smaller lamella distally \pm rounded; dorsal lamina tapering towards the insertion, narrow, straight to slightly rounded at the insertion, reaching the insertion or not, not decurrent; dorsal and apical lamina unistratose with scattered bistratose areas in mid region, juxta-costal 1-2 (-3) stratose; costa poorly defined distally, ending 6-31 cells below the leaf apex, bryoides-type, but frequently irregular, lateral cells few and large, lateral epidermis not to poorly differentiated, with 1 row of 2 large cells or irregular above the vaginant laminae; mid dorsal laminal cells smooth, plane, hexagonal, thin to firm-walled, $6.5-22.5 \times 6.5-14.5 \mu \mathrm{m}$; mid vaginant laminal cells $8.0-29.0 \times 6.5-14.5 \mu \mathrm{m}$; basal vaginant laminal cells oblong, to $38.5 \mu \mathrm{m}$ long, becoming linear-oblong toward the margin; gemmae frequent, manifold; hyaline to brown, filamentous, uni-to multicellular, branched or unbranched fimbriae on marginal cells of all laminae (Fig. 3: 5); epiphyllous hyaline, green or brown, uni- to multicellular, uniseriate, simple or branched filaments (Fig. 3: 6) as well as occasional fascicles of rhizoid-like filaments originating from laminal cells near leaf apices (Fig. 3: 2); axillary, branched or unbranched, filamentous gemmae on rhizoids or directly from cortical cells; axillary fascicles of long unbranched rhizoids with terminal or intercalary areas of short cells separated by transverse cross-walls; stems occasionally, in part, covered with long thick walled rhizoids with cross walls partly oblique and partly transverse that produce multicellular, filamentous, branched gemmae.

Fertile parts. Perigonia and perichaetia terminal on short branches, perigonial and perichaetial

Fig. 3. Fissidens bessouensis Corb. 1 - habit; 2 - leaf with apical cluster of gemmae and perichaetial branches; 3 - leaf; 4 fimbriate leaf apex; 5 - marginal fimbriae; 6 - epiphyllous gemmae; $7 \& 8$ - perichaetial branches; 9 - sporophyte; 10 - sporophytic branch; 11 - peristome; 12 - multicellular spores; 13 - transverse section of stem; 14 - transverse section of leaf. 1 from Vanderpoorten 1647 (private herbarium Bruggeman-Nannenga); 2, 6, 7, 11, 12 from Chevalier s.n. (type of F. bessouensis); $3 \& 8$ from Jones 1539; 4, 5, 13 from Vanderpoorten 1650 (private herbarium Bruggeman-Nannenga); $9,10,14$ from Overlaet 573 (BM). 

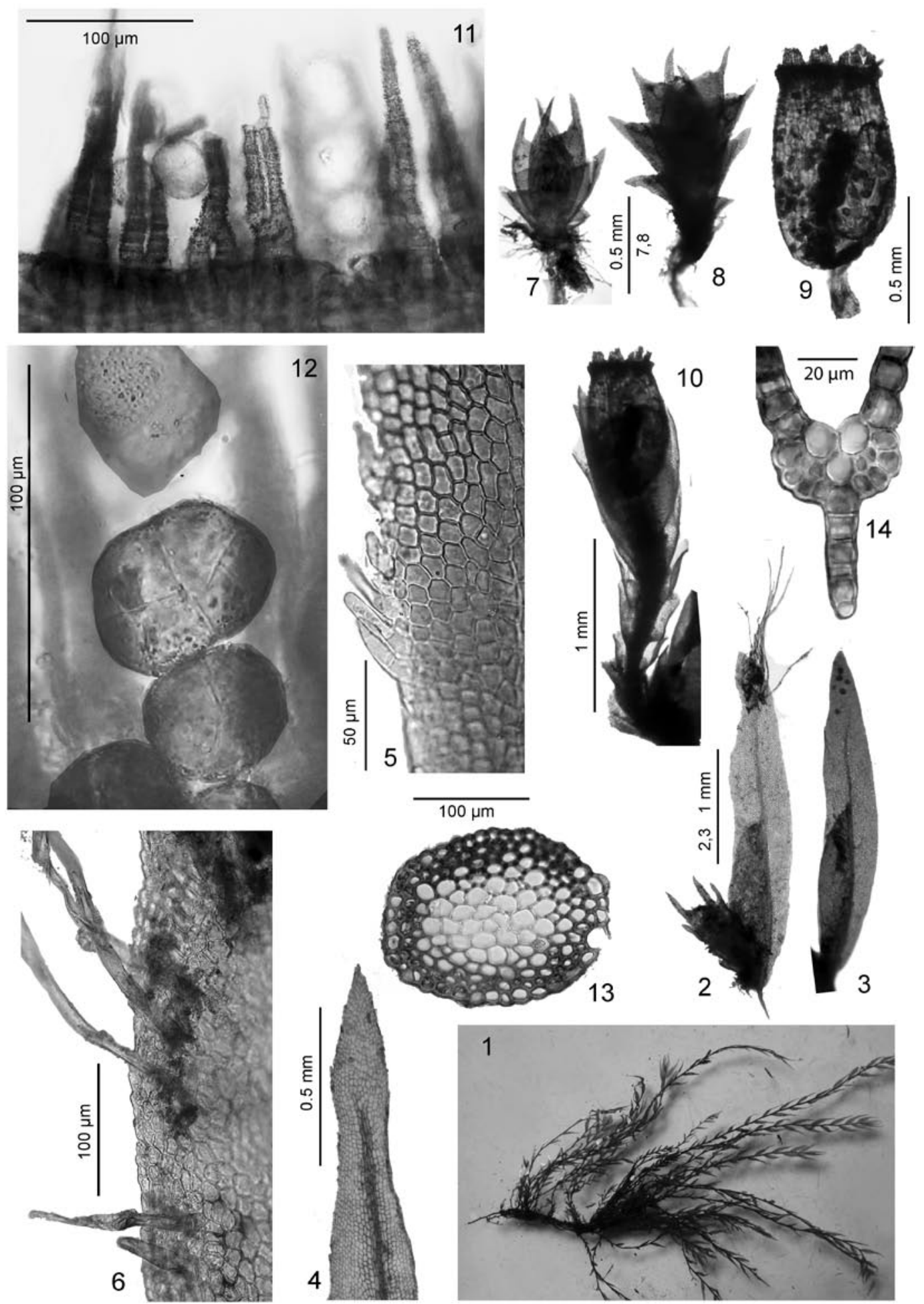
branches frequently in the same leaf axil, 1-5 per axil, tightly attached to the stem by rhizoids; perigonial branches budlike, $0.2-0.5 \mathrm{~mm}$ tall, antheridia 140-210 $\mu \mathrm{m}$ long; perichaetial branches short, 0.5-1.6 (3.4) $\mathrm{mm}$ tall, perichaetial leaves $0.6-0.85 \mathrm{~mm}$ long consisting mainly of a vaginant lamina and a long excurrent costa, apical and dorsal laminae lacking or poorly developed; archegonia 170-260 $\mu \mathrm{m}$ long; sporophyte, seta short almost nonexistent, capsule symmetrical, immersed to emergent, $0.6-1.0 \times 0.4-0.5 \mathrm{~mm}$ with $38-40$ columns of quadratic to oblong exothecial cells; peristome teeth straight, undivided or deeply divided, short, 112-150 $\mu \mathrm{m}$ long, 31-38 $\mu \mathrm{m}$ wide at base, strongly papillose; operculum rostrate, $0.3 \mathrm{~mm}$ long; calyptra not seen (illustrated by Pursell, 1987); spores large, multicellular, 34-45 $\times 29-33.5 \mu \mathrm{m}$ long, slightly papillose, brown.

Fissidens bessouensis is distinguished from other species in subgenus Octodiceras by its \pm open vaginant lamina $2 / 5-2 / 3$ the leaf length with a smaller lamella that is distally more or less rounded (Fig. 3: 2, 3); large multicellular spores (Fig. 3: 12); immersed to emergent sporophytes (Fig. 3: 10); subsessile setae (Fig. 3: 9); small perichaetial (Fig. 3: 7, 8) and perigonial branches; and perichaetial leaves consisting of a wide vaginant lamina plus a rostrum formed by the costa and reduced dorsal and apical laminae. Fimbriate leaf margins (Fig. 3: 5) are frequently found. The stem cortex typically is thin (1 tier) and composed of large thin walled cells, but can be up to 8 tiers of small thick walled cells thick. These differences are probably caused by environmental differences. Fissidens bessouensis usually has the lax look so characteristic of subgenus Octodiceras (Brid.) Broth. (Pursell 1987; Pursell \& Bruggeman-Nannenga 2004), but occasionally it can have the firm appearance of subgenus Fissidens (e.g., the typespecimen of $F$. jordanii). These two expressions are not sharply distinct and, moreover, share the diagnostic features of $F$. bessouensis.

Most Fissidentaceae have stems with a central strand. Central strands are lacking in subgenus Octodiceras and in rheophilous species of several other subgenera (Iwatsuki \& Suzuki 1982; Pursell
\& Allen 1994; Bruggeman-Nannenga 2005). Noteworthy they also lack in a number of terrestrial species, e.g., the acostate subgenus Aloma species. Adaptations of $F$. grandifrons Brid. [subgenus Pachyfissidens (Müll. Hal.) Kindb., section Pachyfissidens] to a rheophilous habitat were discussed by Iwatsuki and Suzuki (1982), and Pursell and Allen (1994). Apart from the absence of a central strand such adaptations include stiff, stream-lined, imbricate, multiseriate leaves, and, astomatose thecae. Species of subgenus Octodiceras, are based on morphological adaptations to sites that for most of the year are inundated often in sheltered places (Pursell \& Bruggeman-Nannenga 2004). Such adaptations similarly include the absence of a central strand and astomatose thecae; long, branched, flaccid floating stems; linear-lanceolate, distant, soft, elimbate or weakly limbate leaves with short costae; and sporophytes with short setae, reduced peristomes and large spores. Adaptations observed in $F$. bessouensis but not studied in other species of the subgenus include multicellular spores, stems firmly attached to the substrate by masses of rhizoids; axillary perigonial, perichaetial and infertile branches firmly attached by rhizoids. Furthermore the formation of many structures that probably function as gemmae (for examples see description and Fig. 3: 2, 5, 6).

Distribution. Sierra Leone, Gabon, Republic of the Congo.

SUBSTRATES. Attached to rocks, twigs of Croton, and on roots.

HABITAT. Rivers, cascades and rapids; submerged occasionally exposed.

SPECIMENS EXAMINED. Sierra Leone, Moa River at Jawo. Jones 1539 (BM); Mange, Bure. H. D. Jordan $851 A$ (holotype of $F$. jordanii PC-PV, isotype of $F$. jordanii: BM). Gabon, prov. Ogooué-Ivindo, Chutes de Kongou sur $1^{\prime}$ Ivindo, $0^{\circ} 17^{\prime} 24^{\prime \prime} \mathrm{N}, 12^{\circ} 34^{\prime} 18^{\prime \prime}$ E. Vanderpoorten GAB1647 (LGHF, private herbarium Bruggeman-Nannenga); rapides de Mbawaka sur le fleuve de l'Ivindo, Vanderpoorten GAB1750 (LGHF, private herbarium Bruggeman-Nannenga). Democratic Republic of the Congo, riverside of Lulua [Lua], near Kalinga. Overlaet $573(\mathrm{BM})$; riv. Lulua. Overlaet s.n. (BR and PC-PV), sine locality. Overlaet s.n. (BR, cum 
sporophytes);Wambali. Vanderijst 1004 (BR), Vanderijst s.n. (BR); Stanleyville, rapides des Wagenia. Leonard 1820 (BR).

ILluSTRATIONS. Pursell, 1987: fig. 23-30; Taylor \& Potier de la Varde, 1954: 507, fig. A-E (as F. jordanii).

ACKNOWLEDGMENTS. I am obliged to Dr. Ron Pursell for his useful comments to an earlier version of this paper, and to the anonymous reviewer for valuable remarks on the manuscript.

\section{REFERENCES}

BRUGGEMAN-NANNENGA M. A. 2005. Two new species of Fissidens (Fissidentaceae, Musci) from Africa, Fissidens harringtonii and Fissidens artsii. Trop. Bryol. 26: 13-17.

BRUgGeman-NANnEnga M. A. 2009. Notes on Fissidens VII - IX. J. Bryol. 31: 106-116.
Bruggeman-Nannenga M. A. \& Pursell R. A. 1995. Notes on Fissidens V. Lindbergia 20: 49-55.

IWATSUKI, Z. \& SUZUKI, T. 1982. A taxonomic revision of the Japanese species of Fissidens (Musci). J. Hattori Bot. Lab. 51: 329-508.

PURSELl R. A. 1987. A taxonomic revision of Fissidens subgenus Octodiceras (Fissidentaceae). Mem. New York Bot. Gard. 45: 639-660.

PURSELl R. A. 2007. Fissidentaceae. Flora Neotrop. Monogr. 101: 1-278.

Pursell R. A. \& Allen B. H. 1994. A re-evaluation of Fissidens subgenus Pachyfissidens, with a detailed discussion of Fissidens grandifrons and F. geijskesii. J. Hattori Bot. Lab. 75: 15-22.

Pursell R. A. \& Bruggeman-NAnNenga M. A. 2004. A revision of the infrageneric taxa of Fissidens. Bryologist 107: $1-20$.

TAYlor J. \& Potier de LA VARde R. 1954. A contribution to the moss flora of tropical Africa. Kew Bull. 4: 505-516. 